\title{
Pine Sawdust as a Roughage Replace- ment in Gestating Beef Heifer Rations
}

\section{A. L. SLYTER AND L. D. KAMSTRA}

Highlight: No abortive tendencies were noted with Angus $X$ Hereford crossbred heifers when fed a corn-roughage ration containing $25 \%$ sawdust during the last one-third of the pregnancy period. Inclusion of sawdust in the ration did not affect the calving difficulty score or birth weights.

Previous studies have shown that pine sawdust levels up to $10 \%$ of the total ration presented no visible toxicity symptoms with calves fed a growing ration during a 90-day period (Kamstra and Minyard, 1970). Also, no detrimental effects on either feedlot performance or carcasses were shown with cattle fed high energy rations for 115 days when sawdust was used to replace half the alfalfa roughage in a $90 \%$ concentrate ration. (Slyter and Kamstra, 1971b).

Sawdust has been suggested as a possible roughage in wintering rations for breeding stock in the range areas when other roughage materials are in short supply. The purpose of this study was to ascertain whether any toxicity might result from incorporating sawdust in wintering rations for pregnant heifers. Special emphasis was given to the possibility of embryonic abortion, since pine needles have been suggested as a causitive factor by Canadian researchers as early as 1927 (Bruce, 1927).

\section{Materials and Methods}

Twelve Angus $\mathrm{X}$ Hereford crossbred pregnant heifers were randomly allotted to two pens of six each. Experimental rations consisted of either $20 \mathrm{lb}$ per head daily of grass and alfalfa loose hay or 20 lb of a mixed ration consisting of $25 \%$ ground corn, $25 \%$ sawdust, and $50 \%$ ground alfalfa hay starting December 24, 1970. These rations were calculated to be approximately equivalent in TDN and crude protein levels. Trace mineral salt and dicalcium phosphate (50-50) were provided free choice. Animals were weighed monthly, calves were weighed at birth, and calving difficulty was subjectively scored (Table 1 , footnote). Animals were taken off treatment at calving.

The authors are with the Department of Animal Science, South Dakota State University Brookings.

The study was conducted at the U.S. De partment of Agriculture Newell Field Station, Newell, South Dakota. The article is published with the approval of the Director of the South Dakota Agricultural Experiment Station as Publication No. 1062 of the Journal Series.

Man uscript received January 27, 1972.
Results and Discussion

No abortive tendencies were observed during this trial. The first calf was born February 18 and the last calf on June 8 . Sawdust feeding was terminated on March 16, since only two animals remained on each treatment. The average calving date was March 23 and March 22 for the control and sawdust groups, respectively. One set of twins was born in the sawdust-fed group, although not attributable to sawdust feeding. Both rations supported adequate weight gains during the period fed (Table 1).

No significant differences were noted in calving difficulty or calf birth weights (Table 1).

Table 1. Weight changes and calving results.

\begin{tabular}{lcc}
\hline \multicolumn{1}{c}{ Ration } & Control & $\begin{array}{c}25 \% \\
\text { Sawdust }\end{array}$ \\
\hline Number in lot & 6 & 6 \\
Average wt 12-24-70 & 878.3 & 883.3 \\
Average wt 03-16-71 $^{1}$ & 904.2 & 925.8 \\
Average calving score $^{2}$ & 1.7 & 2.3 \\
Average birth wt of calves & 56.7 & $59.4^{3}$ \\
\hline
\end{tabular}

${ }^{1}$ Weights included four heifers post-calving and two pre-calving in each lot.

${ }^{2}$ Scored as follows: $1=$ no difficult y; 2 = slightly difficult; $3=$ difficult, calf puller needed; $4=$ extremely difficult.

${ }^{3}$ Includes one set of twins.

Previous work (Kamstra and Minyard, 1970) would suggest that not only is sawdust, fed at levels up to $25 \%$ of the ration, nontoxic, but it serves as a nutritive component as well. They found that fecal excretion of fiber did not increase proportionally with increases in sawdust in the ration. Increasing the level of sawdust from zero to $5 \%$ increased fecal fiber excretion from $39.6 \%$ to $40.0 \%$; but when sawdust was increased to $25 \%$ of the ration, the feces contained only $46.6 \%$ fiber. In vitro dry matter digestibility ranged from 6 to $10 \%$ when used as the only substrate during a 48-hour fermentation period. This would suggest that stock could not be maintained on high sawdust rations unless the sawdust is treated to increase utilization, even if abortive tendencies or other toxicity factors were not critical.

\section{Summary and Conclusions}

Feeding a ration containing $25 \%$ raw pine sawdust to first-calf beef heifers during the last one-third of gestation resulted in no abortion or intake problems. No differences were noted in calf birth weights or calving difficulty in heifers fed the control or sawdust rations. Based on these results, it would appear 
that sawdust could serve as a roughage source in wintering rations for breeding stock up to $25 \%$ of the total ration.

\section{Literature Cited}

Bruce, E. A. 1927. Astragalus serotinus and other stock poisoning plants of British Columbia. Dominion of Canada Dep. Agr. Bull. No. 88, 44 p.

Kamstra, L. D., and J. A. Minyard. 1970. Toxicity study using pine sawdust as a roughage replacement in cattle rations. Proc. S. Dak. Acad. Sci. 49:56-59.

MacDonald, M. A. 1952. Pine needle abortion in range becf cattle. J. Range Manage. $5: 150-155$.

Slyter, A. L., and L. D. Kamstra. 1971. Pine sawdust as a roughage replacement in cattle finishing diets. Fifteenth Annual Cattle Feeders Day, Agr. Exp. Sta., S. Dak. State Univ., Brookings. A. S. Series 71-25. 